\title{
Tóke Anita
}

Szegedi Tudományegyetem JGYPK

ORCID:0000-0002-0935-4505

\section{A sziilók kultúraátadó szerepének változásai, és azok hatásai napjainkban}

\begin{abstract}
Absztrakt
A legrégibb és legmeghatározóbb nevelési tényező a család, amelyben a tagok teljes személyiségükkel vesznek részt, biztosítva a gyermekeknek az éréshez és fejlődéshez szükséges feltételeket. Mindeközben magatartási és szerepmintákat, családi és társadalmi értékrendszert közvetít, felkészítve az egyént a társadalmi szerepvállalásra.

A 20. század utolsó évtizedétől napjainkig a rendszerváltás, a globalizáció és az információs társadalom kialakulásának hatására. nagyon megváltozott a gyermekek társadalmi, gazdasági és kulturális helyzete (uniformizáció, új kulturális profilok stb.). Ezekkel a dinamikusan változó kihívásokkal kell megbirkózniuk a szülőknek, miközben az ő életükön, és gondolkodásukon is folyamatosan nyomot hagy a digitális világ.
\end{abstract}

Kulcsszavak: információs társadalom, szocializáció, digitális világ, szülői szerepek

\begin{abstract}
The Changing Role of Parents as Conveyors of Culture, and Its Contemporary Impact

The oldest and most significant factor in education is the family, in which group members participate with the whole of their personality, providing and ensuring the conditions necessary for the maturity and development of the children. Meanwhile, they also convey behavioral patterns and serve as role models, conveying familial and social value systems, preparing the individual to participate in social interactions.

However, since he last decades of the 2oth century, the emergence of globalization and the information society, the social, economic, and cultural situation of children has changed radically (e.g. uniformization, new cultural profiles, etc.) Parents have to struggle with these dynamically changing challenges, while the digital world does not leave their own lives and thinking untouched, either.
\end{abstract}

Keywords: information society, socialization, digital world, parental roles

\section{Bevezetés}

Az elmúlt 25 évben - pedagógusként és anyaként - mindennapjaim számottevő része különböző korú gyermekek között telik. Ennek köszönhetően közvetlenül tapasztalhattam meg a digitális kor vívmányainak hatásait, és azokat a változásokat, amelyeket gyermekek sokaságánál, szülőknél, családoknál. eredményeztek. A folyamathoz és az általa kialakult helyzethez való hozzáállás, a felmerülő problémák felismerése, valamint azok megoldásaira felállított stratégiák tekintetében igen eklektikus képet kaphattam mind a szülők, mind a pedagógusok részéről. Az viszont a legtöbb esetben elmondható, hogy az alkalmazott „taktika”, módszer, nem idézte elő a kívánt eredményt. Ezt a helyzetet látva, és végiggondolva jutottam arra a következ- 
tetésre, hogy csak akkor tudjuk a lehető legeredményesebben kezelni és kamatoztatni az említett vívmányok hatásait, ha holisztikus szemléletet alkalmazva a lehető legtöbb szempontból megismerjük azokat a társadalmi, szocioökonómiai, fejlődéslélektani és pszichológiai kereteket, amelyek között ezek a változások végbemennek. Ezen keretek feltérképezésének első lépéseként készítettem ezt az tanulmányt, amelyet egy leendő kutatást megalapozó elméleti áttekintésnek szánok.

\section{Társadalmunk változásai}

Az elmúlt harminc évben hazánkban három, egymással összefonódó, a gazdasági, társadalmi és kulturális viszonyokat jelentősen átrendező változás ment végbe. A rendszerváltás, a globalizáció és az információs társadalom kialakulása.

Ebben az átstrukturált világban lehetünk szemtanúi annak, hogyan változik a felnőttek és a gyerekek viszonya, a generációk közti hangnem; milyen új jogok és szükségletek jelennek meg az ifjúság részéről, és hogy hogyan rendeződik át a generációk közti hierarchia. Nyomon követhetjük, hogyan rajzolódik egyre élesebb különbség az információszerzés, a kapcsolattartás és a szabadidő eltöltésének formái tekintetében az egymást követő korosztályok között.

A XXI. századi társadalmunkban a szekularizáció, az individualizáció, az emancipáció, a női karrier, a szexuális tabuk felszámolása, a szexuális jogok érvényesítése és sok egyéb tényező hatására már nem létezik egyetlen családmodell. A családon belül hagyományosnak nevezhető szerepek is gyökeresen megváltoztak. Alternatív családmodellek sokaságában élő szülők a szocializáció elsőrendű közvetítői, a kultúraközvetítés elsőszámú szereplői. Ők adnak keretet annak a folyamatnak, amely során a gyermek elsajátítja az adott kultúra értékeit, szokásait, normáit. Teszik ezt úgy, hogy egyre kevesebb időt képesek gyermekeik nevelésére fordítani, és ezt a nevelésükre fordított anyagiak növelésével kompenzálják.

\section{A szociális közegek változásai}

A család egy informális csoport, amely mintát ad a különböző szerepkapcsolatokra, szimmetrikus és aszimmetrikus viszonyokra, megmutatja a szerepek státuszértékét, a státuszok hierarchiáját és a kölcsönösség elvét. Mindeközben a szülők folyamatosan „fordítanak”, magyarázatot adnak a gyermeket körülvevő világ jelenségeire, eseményeire, azok látható, illetve nem látható okaira a gyermek életkori sajátosságainak megfelelően. Ez segít a fizikai és a társas világban való eligazodás képességének kialakításához, azaz a környezethez való alkalmazkodáshoz.

A gyermek másodlagos szocializációs közege az óvoda, valamint az iskola, ahol az egyén a társadalom által fontosnak tartott normákkal, értékekkel találkozik, miközben megismer az eddig ismerttől eltérő világértelmezéseket, másfajta hierarchiákat. A családhoz füződő érzelmi viszonya lazulni kezd, és elkezdődik a szerepek beválásának megtapasztalása a kortárcsoportokban.

A kortárscsoportok szerepe a szabadidős térben egyre erősebbé válik. Míg a hagyományos szocializációs terek (család, iskola) hatása gyengül, addig a kortárscsoport, mint interakciós közeg befolyása egyre nő. Ebben a közegben van lehetősége az egyénnek gyakorolnia az önkéntességet - hiszen ezekhez a csoportokhoz szabadon lehet csatlakozni, illetve kilépni, - és a kölcsönösség elvét, és ebben a közegben végezhet saját maga számára fontos és hasznos tevékenységeket. (játék, szórakozás), szabadon rendelkezik az idejével. Itt nincs előre meghatározott hatalom és hierarchia.

\section{A globalizáció hatásai}

A fiatalok sajátos szimbólumokkal hoznak létre különböző csoportosulásokat. Ezek a szimbólumok mára globalizálttá váltak. (emo, „plázacica”). Napjaink ifjúságáról megállapíthatjuk, hogy ha a világ különböző kultúrájú országaiban élő kortársaikkal összevetjük őket, jobban hasonlítanak egymásra, mint saját kultúrájuk idősebb tagjaira. Bár a környezet, amelybe ezek a fiatalok születtek, alapvető részletekben különbözik, eltérőek a kulturális szokások, a társadalmi szerepek, a családi struktúrák, a nyelv, a történelmi háttér, a hiedelem-, hagyomány- és normarendszer, azaz a szocializációs háttér, mégis létrejött egy közös tényező, amely mindegyikük fejlődése során jelen van. Környezetük szerves részévé vált a média. A globalizáció mai szintjén a térben, gazdasági és kulturális viszonyokban egymástól távol élő tinédzserek ugyan- 
azokat a divatmárkákat és stílusokat részesítik előnyben öltözködésükben; ugyanazokkal a játékokkal játszanak, ugyanazokért az előadókért és slágerekért rajonganak; ugyanazokat a sztárokat, színészeket, sportolókat tekintik példaképüknek. (Kósa 2004)

\section{A médiatér változásai}

A médiatér tipológiája szerint az „újmédia” korát éljük, amely a digitális kommunikáció révén létrejövő médiaeszközök összességét jelenti. Ezen belül, a web 1.o esetén a szolgáltató biztosítja a tartalmakat, míg a web 2.o kategóriában a tartalmakat maga a közösség teremti, így a felhasználókból tartalomszolgáltatók lettek, és a tudásmegosztás interaktív folyamattá vált.

A fiatalok média- és kultúrafogyasztása ma már egyértelmúen az internet köré szerveződik. Nélkülözhetetlen színtere mindennapi kommunikációjuknak, társas kapcsolataik létrehozásának és ápolásának, önkifejezésüknek, információszerzésüknek, tanulásuknak, szórakozásuknak. Ez a korosztály kevésbé érdeklődik az igényesebbnek tartott kulturális produktumok iránt, mint elődjei, viszont annál öntudatosabban hozza létre saját kultúráját. A „magas” kultúra és a könnyen fogyasztható „alacsony” kultúra sajátos elegyei jelennek meg a kulturális palettájukon. Mindez persze globálisan és uniformizálva, hiszen a médiaeszközök a fiatalok szórakoztatásának érdekében mindig és mindenhol minél könnyebben elérhető és érthető tartalmakat kínálnak. (Jakab 2011) Napjainkban a szocializáció folyamán az egyénnek döntően önmagát kell felépítenie a médiumok nyújtotta ismeret és tudás feldolgozása és beépítése során. De mi nyújt számára segítséget annak eldöntésében, hogy ez az ismeret és tudás számára megfelelő, autentikus és helytálló egy olyan társadalmi hierarchiában, ahol a család, a szülők és az iskola szerepe háttérbe szorul.

A médiumok gyermekekre gyakorolt hatását vizsgáló szakemberek meglátásai két véglet közé esnek. Amíg Niel Postman a médiatechnológia ártalmas és veszélyes hatásaival szemben védelemre szoruló, védtelen és sebezhető gyermekeket vizualizál, addig Don Tapscott a gyermekek velük született bölcsességükkel irányított tudásszomjának kielégítésére csak a médiumok jelenthetnek megoldást. (Jakab 2011) Az igaz, hogy a gyermekeket érő „kívülről” érkező hatások döntően befolyásolják eljövendő felnőtt mivoltuk személyiségét, fogyasztói magatartását, életkori sajátosságaikból adódóan azonban különböző szinten védtelenek és kiszolgáltatottak. Az is nyilvánvaló, hogy tartalmában és idejében kontrollálatlan médiahasználat, valamint a személyes kapcsolatok beszúkülése aggasztó tényező, de emellett a térbeli távolságok miatt akadályozott barátságok, ismeretségek, társas tevékenységek lehetősége igen vonzó. A túlzott média-, és azon belül leginkább az internethasználatra vonatkozólag is létezik egy optimista álláspont, amely szerint a modern eszköz idővel mindig szerves részévé válik a mindennapok egészséges gyakorlatának. Ha ez nem így történik, annak már egy eleve meglévő pszichés probléma az oka. Evvel szemben a pesszimista álláspont veszélyes személyiségformáló hatásokat és függőséget feltételez.

\section{Generációs különbségek, fordított szocializáció}

Az idősebb korosztályoktól való rohamos és néha áthidalhatatlan eltávolodás okai között szerepel az informatika, elektronika és ezek eszközeinek villámgyors fejlődése. Marc Prensky digitális bevándorlónak nevezi a digitális korszak előtt szocializálódókat, akik bármennyire próbálják elsajátítani a technológia nyelvét, számukra az mindig idegen marad. Velük szemben a digitális bennszülöttek szinte az „anyatejjel szívták magukba” a technológiahasználatot. (Prensky 2001.) Ma már a fiatal nemzedéken belül is mikrogenerációk jönnek létre attól függően, hogy az egyének az elektronikai eszközök fejlődésének mely időszakában születtek. (Stein 2013).

Vitathatatlan, hogy mára mindannyian digitális környezetben élünk, így mindannyiunk gondolkodásmódja, viselkedése nagymértékben megváltozott. A miliő, amelyben a gyermekek idejük nagy résztét töltik különböző tevékenységeik során, ugyanaz, amelyben a felnőttek dolgoznak, kommunikálnak, szórakoznak. (Jakab 2011)

Margaret Mead a generációk közötti tudásátadásnak három irányát különböztette meg. A posztfiguratív kultúrában a gyermekek elsősorban szüleiktől, elődeiktől tanulnak, míg a kofiguratív kultúrában a tudásátadás kétirányúvá válik. Említést tesz továbbá a prefiguratív kultúráról, ahol majd az idősebb nemzedék tagjai tanulnak a gyermekektől. (Nyíri 2009) 
Mark Prensky megállapítja, hogy a digitális bevándorlóknak a megváltozott kulturális környezethez való alkalmazkodás, idomulás érdekében gyermekeiktől kell tanulniuk. Ezt a nézetet vallja Don Tapscott is, aki úgy véli, egy „fordított szocializációs” folyamatban a felnőtteknek kell felzárkózniuk a gyerekekhez. Tari Annamária pedig arra hívja fel olvasói figyelmét, hogy „ha valaki jó felnőtt akar maradni, akkor meg kell hallgatnia és hallania a fiatalt, aki szintén rendelkezik már tudással ráadásul olyannal, amelyet az idősebb nem feltétlenül tud megszerezni." (Tari 2010: 189) Ezek a tények nyilvánvalóvá teszik, hogy napjaink ifjúsága új és egyre erősödő tekintélyre tett szert, amely hatással van a társadalmi hierarchiában betöltött szerepére.

\section{Az egyén a tömegkommunikációs térben}

Az infokommunikációs eszközökkel átalakult a fiatalok időháztartása - másképp osztják be és másra használják szabadidejüket - családi és iskolai státusza. Átalakult számukra a kapcsolat, a közösség, a szórakozás, a tanulás fogalma, és beleszületve a digitális korba elődjeikhez képest másképp alakítják át az ismert társadalmat. Számukra az internet a személyes kommunikáció eszköze, az önmegvalósítás tere.

Napjainkban az egyén részvétele a tömegkommunikációs térben 2-6 éves korra, a modern kommunikációs térben 3-8 éves korra tehető, azaz a médiatérbeli eszközök „családtaggá” váltak. (Nagy, Trencsényi 2012) Jelenünkben az emberek mindennapi tapasztalatai nagyrészt a médiumokon keresztül születnek. Tengerparti nyaralásra, téli sítúrákra el nem jutó családoknak is lehet élményük a tengerről, a havas hegyvidékről. A média tükrözi és teremti a valóságot. A befogadók - szülő és gyermek egyaránt - személyes tapasztalat nélkül, közvetett úton szerezhetnek ismeretet, vélt tudást a világ tárgyi és szociális jelenségeiról. A különbség azonban az, hogy ameddig a szülőnek jó esetben megvannak ehhez a folyamathoz az előfeltételei - miszerint rendelkezik a fizikai valóság értelmezéséhez megszerzett kompetenciákkal, pontosan érti a kódolás nyelvét, rendelkezik megfelelő előzetes tudással, tud figyelni a fontos részletekre, - addig a gyermeknek nincsenek. (Berta, Csabai 2014) A befogadási folyamat egyrészről kognitív tevékenység, amely során a nézőnek mindig aktívan kell döntéseket hoznia az értelmezés érdekében; másrészt társadalmi-kulturális meghatározottságú. (Jakab 2011) Ráadásul a látottak reális értékeléséhez és feldolgozásához, elhelyezéséhez egy meglévő tudásrendszerben megfelelő metakognitív képességre és kritikai gondolkodásra is szükség van.

Ennek ellenére a tapasztalatok szerint ez a megismerési folyamat alacsony szintű szülői mediáció mellett történik. A szülő az otthoni, biztonságosnak vélt környezetben jobban „elengedi gyermeke kezét”. egyrészről mert úgy gondolja a képi világ egyértelmú információkat közvetít, másrészről mert a médiumok által közvetített világ nem tűnik számára olyan veszélyesnek, mint a valódi. Sokszor pedig sajnos maga a szülő sem rendelkezik a felsorolt képeségekkel megfelelő mértékben.

A gyerekeknek, fiataloknak szóló tv műsorok, rajzfilmek stb. fogyasztásakor sokan - tévesen úgy gondolják, mivel célzott életkorú közönségnek készültek, nincs szükség magyarázatra, értelmezésre, segítségre a látottak feldolgozásához. Pedig igen gyakran előfordul, hogy az ábrázolás nyelve, a használt szimbólumrendszer is magyarázatot, értelmezést igényel, ugyanúgy, mint a látottak „nem valós” tényének tudatosítása.

Ha a gyerekek szocializációs folyamataira gyakorolt médiahatásról, és a szülők szükséges mediáló szerepéről beszélünk, ki kell térnünk az úton útfélen megjelenő reklámokra, amelyek tartalmai szinte „szüretlenül” zúdulnak a gyerekekre mindenféle médiaeszközön keresztül. A gyerekek 4-5 éves korban nem tudnak különbséget tenni a hirdetések és a többi müsor között. E kor felett már felismerik ugyan a hirdetéseket, de nem tartalmuk szerint, hanem például, hogy milyen vicces, vagy milyen hosszú. A reklámmal kapcsolatos gondolkodási feladat annak felismerése, hogy a reklám célja a közönség meggyőzése, és nem a befogadó, hanem a hirdető érdekeit szolgálja. Erre a felismerésre a gyerekek általában 7-8 éves koruk után válnak alkalmassá. (Sas 2007)

De milyen hatással vannak a reklámok a gyermekek szocializációs folyamataira? A reklám sajátossága a sztereotipizálás, az idealizált álomvilág, az örök fiatalság illúziója, a tökéletesség, mint idea-kép. (Pászthy 2007) Ezek a sztereotípiák negatív hatással vannak énképükre, nemi 
identitásuk fejlődésére. George Gerbner írja a Média rejtett üzenete című tanulmánykötetében, hogy a gyerekeknek életük első 5-6 évében főleg a szülőktől kellene elsajátítaniuk ízlésüket és értékeiket, de ehelyett születésüktől kezdve a televízió által sugárzott történetek, hírek és reklámok állandó és szimbolikus világában élnek. (Gerbner 2000)

\section{A gyermekek helye a társadalmi hierarchiában}

Fontos kérdés a média nyújtotta tartalmak fogyasztásának körülményei, és annak vizsgálata. A mai gyerekek alapvető igénye a saját szoba, lehetőleg akkor is, ha azonos nemú, korban közelálló testvérei vannak. Ez a „saját birodalom” egy privát, szinte intim tér, amelynek tiszteletben tartása alapvető igény. Ez a „saját világ” rendelkezik különböző saját médiahasználati eszközökkel, amelyeket a gyerekek sokszor a saját belátásuk szerint használhatnak az idő és a tartalom tekintetében is, minimális szintű szülői ellenőrzés, mediáció mellett. A „saját világ” számára napjainkra saját médiaipari ágazat épült ki, speciálisan fiatalok számára szóló filmekkel, tv-programokkal, tv-csatornákkal, írott és elektronikus újságokkal, internetes oldalakkal, zenei termékekkel, videojátékokkal. stb.

Láthatóan megváltozott a gyermekek pozíciója a társadalmi hierarchiában. Önálló választással, döntéssel rendelkező jelentős fogyasztói réteget képviselnek. Kiemelkedő szerepet játszanak az új technológiák elterjedésében, amelyek használatára nem egyszer a gyerekek tanítják a felnőtteket, megfordítva az eddigi generációs szokásokat. (Kósa 2016) A gyermekek és szüleik váltak az új technológiák kiemelt felvevőpiacává, és jól látható az is, hogy a gyermekek milyen nagy mértékben képesek befolyásolni szüleik fogyasztási szokásait.

Az eddig említett változások és körülmények nagyban szerepet játszanak abban, hogy a fiatalok napjainkban egyre inkább a horizontális társas kapcsolatok felé fordulnak, a felnőttek és köztük a szülők tekintélye pedig egyre csökken. A médián keresztül szemlélik a felnőttek világát, annak minden árnyoldalával. Láthatnak hazug, jellemgyenge, korrupt, tehetetlen stb. felnőtteket, akár szülői szerepben is. Így a gyerekek azelőtt szembesülnek a felnőtt lét fizikai, lelki és társadalmi csapdáival, mielőtt megfelelő érettséggel készen állnának azok kezelésére. (Kiss 2004)

Neil Postman szerint, míg a korábbi generációk információhoz való hozzáférését a felnőttek szabályozták, mára a felügyelet minimálisra csökkent. Szerinte a gyerekek és a felnőttek közötti különbségek összemosódnak, a gyerekek sok nekik nem való információhoz hozzájutnak, míg a felnőttek gyerekesek maradnak, ugyanazokat a tv müsorokat, sorozatokat, rajzfilmeket nézik, ugyanazokért a zenékért rajonganak, ugyanazokkal a digitális játékokkal játszanak. (Jakab 2011)

\section{Az agyi múködés változásai}

Fontos szempont annak a figyelembevétele is, hogy digitális korunk milyen változásokat eredményezett a ma emberének gondolkodásában, neurológiai rendszerében, képességeiben, hiszen az emberi fejlődéstörténet során jól tetten érhető, a kultúra nagymértékű változásának hatása az emberi gondolkodásra. Az emberi agy plasztikus, folyamatos változásra képes, tapasztalatfüggő struktúra, amelyben átalakulást idéz elő minden külső inger, környezeti hatás. Az internetet aktívan böngészők körében például megfigyelhető a rövidtávú memória fejlődése. (Gyarmathy 2011) Sokan saját bőrünkön tapasztalhatjuk emlékezőképességünk, azaz hosszútávú memóriánk nagyarányú romlását, mivel minden számunkra szükséges információ újra és újra rendelkezésünkre áll, elérhető, anélkül, hogy eszünkbe véstük volna. A gyerekek is hozzáférhetnek minden számukra fontos információhoz, ha megtanulják azt céltudatosan keresni, kritikusan kiválasztani. Ehhez azonban ismét szülői, illetve felnőtt irányításra van szükségük. Hiába oly boldog és büszke sok kisgyermekes szülő, hogy gyermeke már kétévesen be tudja kapcsolni a tabletet és még a kedvenc meséjét is megkeresi és elindítja rajta. Amikor ezek a gyerekek „maguktól megtanulják” a digitális eszközök használatát megelőzve a felnőtteket, valójában csak ezen eszközök múködtetését sajátítják el könnyedébben, ami néhány játék-alkalmazás, vagy tartalomfogyasztással együtt járó applikáció rutinszerü kezelését jelenti. Az informatikai eszközökkel való problémamegoldáshoz, az információ kereséséhez, szűréséhez, ér- 
tékeléséhez, a digitális környezetben zajló megfelelő kommunikáció elsajátításához, az itt történő együttmúködéshez, a digitális tartalom előállításához, a digitális tér biztonságossá tételéhez mindenképpen felnőtt által történő felelős és tudatos irányításra, mediálásra van szükség.

A megszerzett információ akkor válik valódi tudássá, ha azt a gyermek megfelelő módon fel is tudja dolgozni, és használni is képes. Ez a tevékenység azonban egyre több gyerekeknek okoz problémát napjainkban. Szülők és pedagógusok szembesülnek nap mint nap kreatív, intuitív, gyors döntésekre képes, jó humorú gyerekek szövegértési, illetve tanulási problémáival.

Amíg ugyanis Prensky digitális bevándorlóinál - tipikusan bal agyféltekei dominancia mellett, az írás olvasás mindennapi gyakorlatával - az információfeldolgozás elemző módon, logikusan, lépésről lépésre történik; addig a digitális bennszülöttek könnyen befogadják a változó információkat, - gyakran párhuzamosan is (multicasting) -, agilisabban képesek azonnali döntéseket hozni, de a pontos, szisztematikus, tervszerü, rendezett gondolkodás végrehajtásában gyengébbek.

Ennek oka több tényezőből tevődik össze. A digitális bevándorlók képességei jellemzően a bal agyfélte dominanciája mellett formálódtak, így érték őket a megváltozott kultúra hatásai, amelyek a jobb agyfélteke múködésének fokozódó aktivitásához vezettek.

A digitális bennszülöttek képességeinek alakulásánál a gyors, és sok információt hordozó térivizuális ingerek játszanak döntő szerepet a jobb agyfélteke aktív múködése mellett. Szerencsés esetben a két agyfélteke működése így kiegyenlítettebbé válik, hiszen az emberi mivoltunkhoz kapcsolódó beszéd, írásbeliség, verbalitás megtartja a bal agyfélteke erejét. A problémát mégis a bal agyfélteke dominanciájának gyengülése jelenti.

Számos megfigyelés mutatott összefüggést a családok háztartásában lévő különböző digitális eszközök képernyőinek múködési ideje és a családban elő kisgyermek beszédfejlődédének késedelmessége és szegényessége között. A bekapcsolt tévé, számítógép stb. mellett ugyanis a szülő óhatatlanul megosztja figyelmét, kevesebbet beszél a kisgyermekéhez, kevesebb párbeszédet kezdeményez, pedig a két év alatti gyermekek csak valós társas interakciókból képesek a nyelvet megfelelően elsajátítani.

Gyermekeink kész vizuális információkat kapnak azáltal, hogy ritkán hallgatnak meséket képi élmény nélkül, döntően rajzfilmeket néznek, így képzetalkotásuk, azaz a nyelvi sorozatból való saját kép alkotása gyengül, amely a szövegértés alapja. (Gyarmathy 2011)

A kisgyermek döntően vizuális élményszerzése inaktivitással jár, passzív befogadás, amely mellől hiányzik a mozgásos észlelet. Ennek hiánya a szenzomotoros rendszer megkéső fejlődéséhez, illetve bizonyos esetekben alul-múködéséhez vezethet, megzavarhatja a testséma kialakulását az agyban, amelyhez képest válhatnának belsővé a téri irányok. Ez, a precíziós információ, a tapasztalat feldolgozásának nem megfelelő fejlődését eredményezheti, amely kedvezôtlenül befolyásolhatja a gondolkodás pontosságát, a kognitív múködést, valamint a mozdulatok és a vizuális élmény összekapcsolását. (Gyarmathy 2011)

A megfelelő mennyiségű mozgásos tevékenység hiányában, a neurológiai stabilitás kiindulópontja, az egyensúlyi rendszer is gyengébben múködik, amely az információfeldolgozás és a koncentrációs képesség bizonytalanságát eredményezheti. (Gyarmathy 2011)

\section{Új jelenség, a virtuális autizmus}

Itt érdemes említést tenni korunk egyik újszerü jelenségéról a virtuális autizmusról. Ez nem hivatalos fogalom, de különböző riportokban, blogokon szakemberek egyre többször tesznek róla említést. Tájékozódásom során eljutottam Marius Teodor Zamfir tanulmányához, aki ASD-ben diagnosztizált gyermekeknél, 2012-2017 között, két speciális rehabilitációs központban végzett longitudinális felmérést. Kutatása eredményei azt mutatták, hogy azon gyerekek esetében, akik születésüktől hároméves korukig napi 4 óránál többet töltöttek valamilyen virtuális eszköz képernyője előtt a szenzomotoros és a szociális ingerek szegénysége nagymértékben hasonló tüneteket mutatott az autizmus spektrumzavarral diagnosztizált gyermekek tüneteihez. (Zamfir 2018) Első hallásra ez elképzelhetetlenül sok időnek tünik, de ha a figyelembe vesszük a szülők háttér médiahasználati gyakorlatát, illetve a napi teendők elvégzéséhez szük- 
séges nyugalom megteremtésének legkézenfekvőbb megoldását, a „digitális bébiszittert”, valóságossá válik az említett lehetőség. A szülők nincsenek tisztában azzal, hogy valójában milyen károkat okoznak evvel. Ezen kisgyermekek idegrendszerét olyan nagy mennyiségü vizuális inger éri, amelyet már nem tudnak kontrollálni. Könnyen hozzászoknak a virtuális környezethez, nem kíváncsiak a valódi világra, megelégszenek az eszközök adta ingerekkel. Mindeközben hiányt szenvednek azokból az élményekből, amelyeket szüleiktől, családtagjaiktól, gyermektársaiktól kaphatnának Passzívak, kerülik a szemkontaktust, mérsékelt mimikahasználat jellemzi őket, nem képesek szabályozni indulataikat, nyelvi- és beszédfejlődésben korukhoz képest elmaradnak, figyelmük és koncentrációs készségük fejletlen. Az autizmus spektrumzavarral ellentétben azonban a virtuális autizmus esetén jelentős és gyors javulás érhetô el, mégpedig az eszközhasználat jelentős csökkentésével, és a megfelelő ingerek folyamatos biztosításával. Az említett szélsőséges, valós korképet mutató jelenségen kívül is sokat árthat egy szülő az okos eszközök nem megfelelően tudatos használatával, alkalmazásával, amelyekkel ők maguk is jelentős időt töltenek mintát adva gyermekeik számára. Általános jelenség, hogy figyelmük egy bizonyos százalékával mindig a virtuális térben vannak, rá-rá pillantanak egy-egy üzenetre, közösségi oldalra, vagy éppen rákeresnek a napi hírekre esetleg mozimüsorra vacsora közben az asztalnál, vagy a közös Legozás közben. Ritkán tudnak teljes figyelemmel jelen lenni, pedig gyermekük reakciójukból, mosolyukból, érintésükbőll tanulja meg, hogyan reflektáljon környezetére, hogyan oldjon meg helyzeteket. Az okoseszköztől való túlzott függés tehát nemcsak a gyermekeket, hanem szüleiket is érinti, tudatos és következetes, példát adó magatartásuk elengedhetetlen.

\section{Zavarok a személyiségfejlődésben}

Az Egészségügyi Világszervezet (WHO) és az Amerikai Gyermekorvosok Társasága (AAP) 2 éves kor alatt teljes mértékben ellenzi a csecsemők és kisgyermekek okoseszköz és média használatát. 2 és 5 éves kor között napi maximum 1 óra, szülői felügyelet mellett töltött képernyőidőt ajánl. (WHO 2019) Ezzel szemben a mindennapi gyakorlat azt mutatja, hogy a szülők nagy része a gyermek elfoglalására például házimunka végzése vagy autózás közben, étkezéskor, illetve a gyermekek megnyugtatása céljából, tabletet, okostelefont ad gyermeke kezébe, illetve televízió elé ülteti, sőt a gyermek elaltatásához is segítségül hív valamilyen digitális eszközt. Ez a rutin teljes mértékben ellentétes azzal az javalattal, hogy egy órával elalvás előtt már egyáltalán ne legyünk képernyő előtt, mivel az rontja az alvás minőségét. Ilyenkor a gyermekek azonnal a képernyőre fókuszálnak, a külvilág megszűnik számukra, látszólag azonnal megnyugszanak. A szülők pedig egyáltalán nincsenek tisztában azokkal a hátrányos folyamatokkal, amelyek ilyenkor gyermekeikben zajlanak. A kisgyermekek megnyugvásához, szorongásuk, félelmük, fájdalmuk feloldásához egy felnőtt személyre van szükségük, amely folyamat személyiségfejlődésük szempontjából döntő jelentőségű. Mintát kapnak arra, hogyan lesznek képesek később saját magukat megnyugtatni, kezelni érzéseiket, félelmeiket, szorongásaikat, stresszhelyzeteiket. Az okos eszközök helyettesítő szerepével a személyiségfejlődés egy fontos körülménye nem adatik meg számukra. Erre a hatásra a szervezetükben zajló hormonális folyamatok is ráerősítenek. Ha a gyermek azt éli át, hogy kiszámíthatóan rendelkezésre állnak a szülei, amikor szüksége van rájuk, szervezetében oxitocin kezd termelődni, amely a biztonságos kötődés kialakulásáért is felelős. Ezzel szemben az okostelefon használata során dopamin termelődik, ami ugyan rövidtávú élvezetet okoz, de hosszú távon nem enyhíti a hiányérzetet, vagy a stresszt, ellenben hozzájárul a sóvárgás és függőség kialakulásához. A tárgyakhoz ugyanis nem kötődünk, hanem függővé válunk tőlük. Azok a kamaszok és felnőttek, akik kisgyermekkorukban érzelmi szükségleteikre válaszként személyek helyett tárgyakat kaptak, hajlamosabbak lesznek a drogfogyasztásra, függőségek kialakulására. (Pál 2019). Minden örömet adó tevékenységünk (rajz, tánc, zene, játék, sport hobbi stb.) során dopamint termel szervezetünk, mintegy jutalom gyanánt erőfeszítéseinkért. Ezekkel a belső dopamintermelő tevékenységekkel szemben a digitális élményeket kísérő külső dopamintermelés úgy biztosít örömforrást, hogy a valójában semmit sem kell tennünk érte. A könnyen, gyorsan szerzett sok dopamintól pedig könnyü függővé válni. (Uzsalyné 2020) 
A megoldás a felsorolt problémákra ebben az esetben is a szülők kezében van. Az okoseszközök életünk szerves részeként vannak jelen kultúránkban, eldobni őket, elhatárolni tôlük magunkat és gyermekeinket értelmetlen és lehetetlen. A szülőknek meg kell tanulniuk és tanítaniuk tudatos következetes és optimális használatukat.

\section{Szülői stratégiák}

A digitális generációt leíró tanulmányok egyik kitüntetett terepe az internet szülő-gyermek kapcsolatára gyakorolt hatása. A szakirodalom különböző stratégiákat azonosított az internethasználat szülői kontrollja kapcsán, amelyeket más médiumok esetében is megfigyelhetünk, alkalmazhatunk.

Az aktívan résztvevő szülő beszélget gyermekével a különböző médiumok használatáról, az ott található tartalmakról, időnként használat közeben, a szükséges helyzetben. Ezek a gyerekek rendszerint kritikusabbak a látott tartalmakkal szemben, de a stratégia végkimenetelét nagymértékben befolyásolják a gyermek egyéni jellemzői, neme, kora, szocioökonómiai státusza. Az interakció-korlátozó szülő határt szab a használat ideje, helye, vagy mindkettő tekintetében legtöbbször tiltás formájában. Többségük sem személyes jelenléttel nem próbálja segíteni a médiák sugározta tartalmak megértését, az információk osztályozását, feldolgozását; sem technológiai kontrollal, szűrőkkel, szülői felügyeleti szoftverekkel nem próbálja megelőzni a negatív hatásokat. A technikai korlátozó szülő él a fent említett lehetőségekkel, alkalmazza azokat. A figyelő szülő viszont jelen is van gyermekével médiahasználata során, akár együtt is használják, megosztják az élményt, a szülő esetenként kommentálja is a látottakat, hallottakat. (Ujhelyi 2015).

\section{Összegzés}

Összességében elmondható, hogy a médiumok, digitális eszközök, az internet szerves és immár nélkülözhetetlen, megkerülhetetlen része életünknek, mindennapjainknak. Ezen eszközök egészséges korlátok és szabályok között történő használata kifejezetten előnyös lehet, kifogyhatatlan mennyiségú információval, a szociális kapcsolatok kiépítésével, fenntartásával, erősítésével járhat. Ehhez azonban a gyermekeknek olyan felnőttek irányítására van szükségük, akik értenek a technikához, amit gyermekeik használnak; tisztában vannak az okoseszközök és a médiumok hatásával a gyermekek idegrendszeri, érzelmi és értelmi fejlődése, szocializációs folyamataik, társas létük szempontjából. A korlátok és szabályok megalkotása mindenképp alapos megfontolást igényel, mert például az internetezési idő szigorú és kizárólagos korlátozása hátránnyal is járhat a napi információ megszerzése tekintetében. A nem kívánt tartalmakhoz viszont a korlátozott idő alatt is hozzájuthat a gyermek, de tudomást szerezhet róla egy barát vagy osztálytárs eszközén keresztül, vagy akár szóbeli beszámolója révén is. Hasonló a probléma a különböző szűrőprogramok tekintetében. Ezek rendkívül hasznosak mindaddig, amig a gyermek a saját, általunk ellenőrzött eszközhöz fér hozzá, de az már nehezen kontrollálható, hogy társaik digitális tevékenységeit figyelemmel kísérve milyen információkhoz jutnak. Így az elóbb említett két stratégia mellett is nélkülözhetetlen a szülők mediáló, kultúraközvetítő tevékenysége, példamutatása; folyamatos reflektálása gyermekeikre, azok gondolataira, élményeire, beszámolóira. Ehhez azonban meg kell tartaniuk hitelességüket, amelynek egyik feltétele az, hogy otthonosan mozogjanak gyermekeik világában, ismerjék kedvenc előadóikat, műsoraikat, filmjeiket, sportolóikat stb. Mindenképp szükséges lenne a szülők minél szélesebb körű tájékoztatása, hogyan vezessék gyermekeiket az online térben, és a médiumok sugározta világban, hogyan segítsék ôket a mérhetetlen mennyiségü inger, élmény és információ feldolgozásában; milyen árulkodó jelekre figyeljenek, amik a problémás internethasználatra vagy esteleg - bár tanulmányomban erre a területre nem tértem ki - internetes zaklatásra utalhatnak. Gyermekeik érdekében legyenek tisztában a digitális világ előnyeivel, hátrányaival és csapdáival egyaránt; törekedjenek a folyamatos tájékozódásra, tudatos irányításra akkor is, ha családi életük diszfunkcionális kapcsolatokkal terhelt, egyedülálló szülőként nevelik gyermekeiket, és a családfenntartás idejük jó részét felemészti. Tegyék ezt újra és újra azért, hogy megfelelő mértékben tudják befolyásolni és irányítani gyermekeik fejlődését, szocializációját, felnőtté válását. Ehhez szeretnék hozzájárulni a téma további tanulmányozásával, amelynek következő lépése egy empirikus kutatás elvégzése, valamint eredményeinek feltárása, értékelése, kifejtése. 


\section{Irodalom}

Berta J., Csabai K. (2014). Szocializáció gyermek és serdülókorban. Elakadások, zavarok és kibontakozás. Pázmány Péter Katolikus Egyetem Bölcsészet- és Társadalomtudományi Kar egyetemi jegyzet.

Gerbner, G. (2000). A média rejtett üzenete. Osiris Kiadó.

Gyarmathy É. (2011). A digitális kor és a sajátos nevelési igényű tehetség. Fordulópont 51. 79-88.

Jakab Gy. (2011). Szocializáció és média - a diákok és az internet. Új Pedagógiai Szemle 61. évf. 8-9. 121-143.

Kiss J. (2004). A televízió hatása a kisiskolás gyerekekre. Új Pedagógiai Szemle 54. évf. 9. 35-59.

Kósa É. (2004). A média szerepe a gyerekek fejlődésében. Mindentudás Egyeteme 5. kötet 165-187. Kossuth Könyvkiadó.

Kósa É. (2016). A média: a változások oka vagy eszköze? Gyermeknevelés 4. évf. 2. szám 48-68.

Nagy Á., Trencsényi L. (2012). Szocializációs közegek a változó társadalomban. A nevelés esélyei: család, iskola, szabadidő, média. ISZT Alapítvány, Budapest.

Nyíri K. (2009). Tanulás és tudás a mobil világban. In: Benedek A., Hunyadi Gy. (szerk.). „Az oktatás közügy". A VII. Nevelésügyi Kongresszus zárókötete. Magyar Pedagógiai Társaság.

Pál F. (2019). Ami igazán számít - Hogyan bánjunk jól magunkkal és másokkal? Kulcslyuk Kiadó, 193-211.

Pászthy B. (2007). A média által közvetített ideálok hatása a gyermekek és serdülők testképére. „Párbeszéd a médiáról” konferencia-sorozat. A kiskorúak védelme a médiaszolgáltatásokban. Alkalmazott Kommunikációtudományi Intézet. 18-23.

Prensky, M. (2001). Digital Natives, Digital Immigrants. https://marcprensky.com/writing/Prensky\%20\%20Digital\%2oNatives,\%2oDigital\%20Immig rants\%20-\%20Part1.pdf. Utolsó letöltés: 2020. 12. 28.

Sas I. (2007). Reklám és Pszichológia. Budapest, Kommunikációs Akadémia Könyvtár.

Stein, J. (2013). Millenials: The Me Me Me Generation. The Times Magazine, May 20. 30-35.

Tari A. (2010). Y generáció. Klinikai pszichológiai jelenségek és társadalomlélektani összefüggések az információs korban. Jaffa Kiadó

Ujhelyi A. (2015). Az internet mint szocializációs közeg. In: Kósa É., Berta J. (szerk.). Médiaszocializáció. Wolters Kluwer Kiadó.

Uzsalyné P. R. (2020). Fejleszt vagy rombol? Kulcs az okoseszközök okos használatához. Kulcs a Muzsikához Kiadó.

World Health Organization (2019). Guidelines on physical activity, sedentary behaviour and sleep for children under 5 years of age. https://www.who.int/publications/i/item/9789241550536. Utolsó letöltés: 2021. 01. 05.

Zamfir, M. T. (2018). The consuption of virtual environment more than 4 hours/day, in the children between 0 -3 years old, can cause a syndrome similar with the autism spectrum disorder. https://www.researchgate.net/publication/323748812_THE_CONSUMPTION_OF_VIRTUA L_ENVIRONMENT_MORE_THAN_4_HOURSDAY_IN_THE_CHILDREN_BETWEEN_O3_YEARS_OLD_CAN_CAUSE_A_SYNDROME_SIMILAR_WITH_THE_AUTISM_SPECTR UM_DISORDER. Utolsó letöltés: 2021. 06. 23. 